\title{
Biological activities of phenolic compounds extracted from flaxseed meal
}

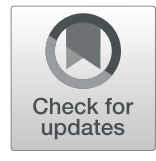

\author{
Engy M. Akl ${ }^{1 *}$ D, Samira S. Mohamed ${ }^{1}$, Ahmed I. Hashem² and Fakhriya S. Taha ${ }^{1}$
}

\begin{abstract}
Background: There is a worldwide demand for phenolic compounds (PC) because they exhibit several biological activities. The present investigation deals with a comprehensive study on the biological activities of phenolic compounds extracted from flaxseed meal (FM) with the aid of ultrasonic waves.

Results: The antioxidant activity of the PC extract of FM is considerably high when measuring it by the three methods (the $\beta$-carotene coupled oxidation method, the DPPH free radical scavenging activity method, and measuring the reducing antioxidant power). The toxicity test revealed that the PC extract was nontoxic on normal retina cell line. Also, it has no anticoagulating activity. Evaluation of antimicrobial activity showed that it is effective towards four strains only from seven. FM phenolic extract has been evaluated as chemo-preventive agents by testing the product for any cytotoxic activity against human tumor cell lines. The highest inhibitory effect was achieved on cell lines of colon carcinoma and lung carcinoma with $\mathrm{IC}_{50}=22.3$ and $22.6 \mathrm{\mu} / \mathrm{ml}$ respectively.

Conclusion: The PC extracted from FM showed high antioxidant activity, nontoxic on normal retina cell line, no anticoagulating activities, and an antimicrobial effect on some pathogenic bacteria, so the phenolic compounds extracted from flaxseed meal showed significant biological activities.
\end{abstract}

Keywords: Flaxseed meal, Phenolic compounds, Antioxidant, Antimicrobial, Anticoagulant, Cytotoxicity, Anticancer

\section{Introduction}

The components of flaxseed meal were found to have a wide spectrum of biological activity. Utilization of flaxseed has been shown to exhibit a huge number of advantages to health including the diminishing rate of tumor development, lowering serum cholesterol level, and diminishing rate of breast, prostrate, and colon diseases (Muir et al. 2003; Hemmings et al. 2004; Hosseinian et al. 2006; Choo et al. 2007).

Early research showed that flaxseed possesses a very powerful antioxidant system; ground and whole flaxseeds were stable at room temperature for numerous months [Chen et al. 1994; Malcolmson et al. 2000]. Ground/milled and whole flaxseeds stored showed negligible oxidative deterioration at room temperature, which indicates the presence of an efficient antioxidant system, where compounds other than tocopherols may play an important function [Chen et al. 1994); Malcolmson et al. (2000); Hosseinian et al. (2006)].

\footnotetext{
* Correspondence: engy_akl@yahoo.com

${ }^{1}$ Fats and Oils Department, National Research Centre, Dokki, Cairo, Egypt Full list of author information is available at the end of the article
}

Flaxseed is particularly rich in lignans, e.g., secoisolariciresinol diglucoside (SDG), which are also present in flaxseed oil. These components have some antioxidant activity (Hosseinian et al. 2006). The proved functions of lignans are related to health benefits and the protection from some types of cancer and heart diseases [Kim and Ilich 2011; Park and Velasquez 2012; Ayella et al. 2010; Rodriguez-Leyva et al. 2010]. Besides lignans, flaxseed contains 8:10 $\mathrm{gkg}^{-1}$ of phenolic acids, mainly $\mathrm{p}$ coumaric, vanillic, sinapic, and ferulic, which are present in the seed as glycosides with ester and ether bonds [Oomah et al. 1995); Johnsson (2004)]. Phenolic acids have antioxidant activities, related to the positions of hydroxyl groups on the ring [Przybylski and Daun 2005); Tuberoso et al. (2007)].

Previous studies demonstrated that the antioxidant compounds enhance human health, for example, restraint of tumor cells, enhancing the state of cardiovascular sicknesses and diabetes [Żuk et al. 2011], curing human chronic ulceration [Skórkowska-Telichowska et al. (2010)], against allergenic, hostile to atherogenic, mitigating against microbial, antioxidant, against 
thrombotic, cardioprotective, and vasodilatory impacts [Benavente-García et al. 1997].

Khouya et al. (2015) evaluated several biological activities including anticoagulant, anti-inflammatory, and antioxidant from aqueous extracts of thyme varieties. Wee et al. (2010) extracted active compounds from Korean red ginseng which were identified as phenolic compounds (namely vanillic, caffeic, ferulic, and p-coumaric acid). These products possess anticoagulant activities. Daud et al. (2013) stated that the ethanolic extracts from Averrhoa bilimbi even from fruits or leaves showed a considerable anticoagulant effect on rats.

Plants produce a large number of organic compounds that possess antimicrobial activity. The compounds are found in various parts of plant such as leaves, bark, stems, roots, fruits, flowers, or and seeds. These compounds include alliin/allicins, isothiocyanates, plant pigments [Cutter 2000], proteins, hydrolytic enzymes, essential oils [Smid and LGM 1999], and phytoalexins or phenolic compounds [Cutter 2000; Smid and LGM 1999].

A huge number of chemical compounds are present in seeds or seed coats, including alkaloids, lectins, and phenolic compounds such as lactones, tannins, and flavonoids. These compounds play a role in the seed protection from microbial attack until conditions are improved for germination [Cai et al. 2004; Komutarin et al. 2004].

Dietary use of seedcake is effective; it is utilized against number of diseases, as skin diseases, respiratory tract diseases, and gastrointestinal tract diseases. Secoisolariciresinol diglucoside (SDG) is the richest components of flaxseed cake, the precursor of lignans, which have many advantages on human health. SDG is known to possess anticancer properties by reducing cell proliferation and growth, especially in breast and prostate cancer [Wang et al. 2005]. SDG, which has also antimicrobial effect including anti-viral, antibacterial, and anti-fungal properties, is an antioxidant, and it has been shown to improve immune system functioning [Adolphe et al. 2010]. Besides that flaxseed cake includes phenolic acids, flavonoids, and other phenylpropanoids, it is known to have antioxidative properties and thus having helpful actions on human health [Korkina 2007].

Intact flaxseed is generally considered as a healthy food that has anticancer action. Controlled trial diets have exhibited various valuable impacts of flaxseed utilization [Clark et al. 1995; Cunnane et al. 1993; Jenkins et al. 1999]. Dietary flaxseed cake decreases epithelial cell generation and nuclear deviation in mammary glands of female rats. This finding showed that flaxseed may lessen the development rate of mammary tumor (Serraino and Thompson 1991). Furthermore, it has been noticed that flaxseed lignan diminishes mammary tumor development in the later phases of carcinogenesis (Thompson et al. 1996). Essentially, it has been demonstrated that the substitution of corn meal, with flaxseed meal $(15 \%)$ or corn oil with flaxseed oil (15\%) in a basal eating routine, diminished tumor generation and size in the small digestive system and colon of Fischer 344 male rats. The creators presumed that flaxseed meal and oil are successful chemo-preventive operators (Bommareddy et al. 2009).

In a recent publication (Akl et al. 2017), the same authors reported on the extraction of phenolic compounds (PC) from flaxseed meal (FM) using a variety of extraction techniques, and then evaluated its phenolic contents of each method. The present investigation aims to deal with a comprehensive study on the biological activities of optimum condition obtained by ultrasonic assisted extraction. Some biological activities of these phenolic extracts (antioxidant, antimicrobial, anticoagulation, and anticancer effects) were evaluated.

\section{Materials and methods \\ Materials}

One hundred grams of flaxseed meal were added to 31 of distilled water and stirred well then transferred to ultrasonic bath for $2 \mathrm{~h}$ at $35{ }^{\circ} \mathrm{C}$ then centrifuged to give the supernatant which contains the phenolic compounds. This crude extract was purified then freeze dried by Crest Alpha 1-4 LSC plus, Germany, and reserved in refrigerator until use.

\section{Methods}

\section{$\beta$-Carotene coupled oxidation method}

Determination of the AOA of the extracts was based on the coupled oxidation of $\beta$-carotene and linoleic acid according to the method of (Taga et al. 1984), with some modifications. $\beta$-Carotene $(0.1 \mathrm{~g})$ was dissolved in $20 \mathrm{ml}$ of $\mathrm{CHCl}_{3}$ solution. Three milliliters of aliquots of the former solution was added to a round bottom flask along with $40 \mathrm{mg}$ of linoleic acid and $400 \mathrm{mg}$ Tween 20. Chloroform was evaporated until dryness under reduced pressure at low temperature (less than $30^{\circ} \mathrm{C}$ ). One hundred milliliters distilled water were added to the dried mixture and mixed well ( $\beta$-carotene emulsion. Aliquots from the PC extracts to be examined ( $500 \mu \mathrm{l}$ each) were added to $5 \mathrm{ml}$ $\beta$-carotene emulsion and incubated in a water bath at 50 ${ }^{\circ} \mathrm{C}$ for $(60 \mathrm{~min})$. Absorbance of the sample was measured against blank at $470 \mathrm{~nm}$ after $60 \mathrm{~min}$. A blank sample formerly prepared ( $40 \mathrm{mg}$ linoleic acid and $400 \mathrm{mg}$ Tween 20 in distilled water). Also, an aliquot (500 $\mu \mathrm{l} \mathrm{PC} \mathrm{extract}$ added to $5 \mathrm{ml} \beta$-carotene emulsion) was shaken well and measured immediately (zero time).

The degradation (Dr) of $\beta$-carotene was calculated using the first order kinetic equation:

Dr of sample $=\ln \left(A^{\circ} / \mathrm{At}\right) / T$ 
where $A^{\circ}=$ absorbance of sample (PC extract)-absorbance of blank at zero time

At $=$ absorbance of sample-absorbance of blank at $t$ time $T=60 \mathrm{~min}$ of incubation at $50{ }^{\circ} \mathrm{C}$

Dr of control sample $=\ln \left(A^{\circ} / \mathrm{At}\right) / T$

where $A^{\circ}=$ absorbance of control sample at zero time

At $=$ absorbance of control sample at time $t(60 \mathrm{~min})$ at $50{ }^{\circ} \mathrm{C}$

Antioxidant activity was expressed as:

AOA\% $=$ Dr of control sample - Dr of sample $\times 100 /$ Dr control sample.

\section{Determination of antioxidant activity by the DPPH free radical scavenging activity method}

The scavenging activity of DPPH free radicals were measured according to (Zhao et al. 2008). DPPH solution was prepared by dissolving $4 \mathrm{mg}$ of DPPH in $100 \mathrm{ml}$ methanol (it has a violet color). Four milliliters of DPPH solution and $0.5 \mathrm{ml}$ of PC extract were mixed. The mixture was shaken vigorously and left in the dark to stand at $30^{\circ} \mathrm{C}$ for $30 \mathrm{~min}$.

A blank for each sample was prepared: $0.5 \mathrm{ml}$ of sample with $4 \mathrm{ml}$ methanol. Four milliliters of methanolic DPPH solution against methanol served as control.

Decolorization of the methanolic DPPH solution was determined by measuring the decrease in absorbance at $517 \mathrm{~nm}$ using a spectrophotometer model (UV-VIS Spectrophotometer PG Instruments, UK), and DPPH was calculated according to the following equation:

Scavenging rate $=(1-(\mathrm{A} 1-\mathrm{A} 2)) \times 100$

where A1 represents the absorption of the sample PC extract and A2 represents the absorbance of control.

\section{Measuring the reducing antioxidant power}

The reducing antioxidant power of the PC extracts was measured according to the method of (Oyaizu 1986). Different concentrations of the PC extract (500 ppm) completed to $1 \mathrm{ml}$ of distilled water were mixed with sodium phosphate buffer (2.5 ml, 1\%), then $2.5 \mathrm{ml}$ of $1 \%$ potassium ferricyanide $\left(\mathrm{K}_{3} \mathrm{Fe}(\mathrm{CN})_{6}\right)$ was added to the mixture. The mixture was incubated at $50^{\circ} \mathrm{C}$ for $20 \mathrm{~min}$ then $2.5 \mathrm{ml}$ of trichloroacetic acid (10\%) were added, then centrifuged for $15 \mathrm{~min}$ at $3000 \mathrm{rpm}, 2.5 \mathrm{ml}$ of the upper layer of solution of the mixture were mixed with distilled water $(2.5 \mathrm{ml})$ and $\mathrm{FeCl}_{3}(0.5 \mathrm{ml}, 0.1 \%)$ and were mixed well. The absorbance was measured at $700 \mathrm{~nm}$ a blank using a spectrophotometer model (UV-VIS Spectrophotometer PG Instruments, UK). The increased absorbance of the reaction mixture indicates increase in reducing power.

\section{Determination of antimicrobial activity}

The antimicrobial activity of FM phenolic extracts of different concentrations was determined by the agar well diffusion method [Con et al. (2001)]. The seven pathogenic indicator bacteria strains were obtained from the stock cultures of the Dairy Microbiological Lab, National Research Centre: Escherichia coli 0157: H7 ATCC 6933, Bacillus cereus ATCC 33018, Staphylococcus aureus ATCC 20231, Salmonella typhimurium ATCC 14028, Pseudomonas aeruginosa ATCC 9027, Listeria monocytogenes ATCC 7644, and Yersinia enterocolitica ATCC 9610. Each strain was activated in tryptone soy broth by fermentation at $37^{\circ} \mathrm{C}$ for $24 \mathrm{~h}$. One milliliter culture of the activated indicator strain $(105$ cells $/ \mathrm{ml})$ was inoculated into $20 \mathrm{ml}$ of Mueller-Hinton agar (Becton Dickinson, USA) and poured in petri dishes. After solidification of the agar, wells of $5 \mathrm{~mm}$ in diameter were cut from the agar with a sterile borer, and $50 \mu \mathrm{l}$ of phenolic extract were introduced in each well. Dishes were incubated for 24 h at $37^{\circ} \mathrm{C}$.

The zone diameter of wells cut in Mueller-Hinton agar was $5.0 \mathrm{~mm}$, and the diameter of inhibition zone (DIZ) of negative a control for each bacterium was also 5.0 $\mathrm{mm}$. If the DIZ value is $5.0 \mathrm{~mm}\left({ }^{*}\right)$, it means the sample has no inhibitory activity against that bacterium. The diameters of the inhibition zones were measured (Rammelsberg and Radler 1990).

\section{Cytotoxic effect on human normal retina cell line (RPE1)}

Cell viability was assessed by the mitochondrial dependent reduction of yellow MTT 3-(4,5-dimethylthiazol tetrazilium bromide) to purple formazan (Bassyouni et al. 2014).

\section{Determination of anticarcinogenic effect Cell line Carcinomas}

Liver carcinoma cell line (HEPG2), larynx carcinoma cell line (HEP2), colon carcinoma cell line (HCT), cervical carcinoma cell line (HELA), breast carcinoma cell line (MCF7), intestinal carcinoma cell line (CACO), and normal melanocytes (HFB4) were supplied and used in The National Cancer Institute, Biology Department, Cairo, Egypt, and the evaluation was done by the SulfoRhodamine-B stain (SRB) assay, according to the method of Skehan et al. (1990).

\section{Anticoagulation assay}

The clotting times were measured using a blood coagulation analyzer (Behnk Elektronik Norderstedt, Germany). To measure the thrombin time (TT), $50 \mu \mathrm{l}$ of $0.02 \mathrm{MCaCl}_{2}, 50 \mu \mathrm{l}$ of thrombin, and $50 \mu \mathrm{l}$ of sample were pre-incubated at $37{ }^{\circ} \mathrm{C}$ for $3 \mathrm{~min}$. The coagulation reaction was started by the addition of $100 \mu \mathrm{l}$ of citrated human plasma. 
Table 1 Antioxidant activity of FM phenolic extracts as measured by three different methods

\begin{tabular}{llll}
\hline $\begin{array}{l}\text { PC extract } \\
\text { flaxseed meal }\end{array}$ & $\begin{array}{l}\beta \text {-Carotene } \\
\text { method, } \%\end{array}$ & $\begin{array}{l}\text { DPPH } \\
\text { method, \% }\end{array}$ & $\begin{array}{l}\text { Reducing antioxidant } \\
\text { power, } \mu \mathrm{g} / \mathrm{g}\end{array}$ \\
\hline & 73.52 & 55.28 & 4240
\end{tabular}

\section{Results}

The antioxidant activity of the PC extract of FM is considerably high when measured by the three methods. The antioxidant activity of PC extract (Table 1) prepared by UAE from FM was determined by three methods: (1) $\beta$-carotene coupled oxidation method, (2) DPPH free radical scavenging activity method, and (3) the reducing antioxidant power. The results of the three experiments proved that FM PC extract possessed antioxidant power. $\beta$-Carotene, DPPH method, and reducing antioxidant power were: 73.52, 55.28 and 4240, respectively, for FM extract. BHT as a control measured $82.91 \%$ by $\beta$ carotene method, $61.72 \%$ by DPPH method, and 5745 $\mathrm{mg} / \mathrm{g}$.

The results in Table 2 reveal that FM phenolic extract was nontoxic according to the conditions of the experiment stated in the experimental part.

The phenolic extracts of FM showed various degrees of inhibition against the seven bacterial strains using the agar well diffusion method as represented in Table 3. FM phenolic extract inhibited the growth of 4 out of 7 of the tested bacteria. FM extract had nil effect on the following three strains, Yersinia enterocolitica, Bacillus cereus, and Staphylococcus aureus. Listeria monocytogenes was inhibited by FM extract by $26 \mathrm{~mm}$ inhibition zone diameter, Salmonella typhimurium inhibition zone diameter $25 \mathrm{~mm}$, Escherichia coli inhibition zone diameter $22 \mathrm{~mm}$, and Pseudomonas aeruginosa inhibition zone diameter $10 \mathrm{~mm}$.

The results of coagulant activity of the phenolic extract are listed in Table 4, indicates that conc. 2.0 and $1.0 \mathrm{mg} / \mathrm{ml}$ of FM phenolic extract presented no clotting activity, while at $5.0 \mathrm{mg} / \mathrm{ml}$ clotting happened after 19.0 s, so the FM extract showed almost no anticoagulating activities.

FM phenolic extract have been evaluated as chemopreventive agents. This was established by testing the product for any cytotoxic activity against the following human tumor cell lines (Table 5).

Normal fibroblasts (BHK), intestinal carcinoma cell line $(\mathrm{CACO})$, breast carcinoma cell line (MFC7), colon

Table 2 Cytotoxic activity of FM phenolic extracts

\begin{tabular}{ll}
\hline Sample code & Remarks \\
\hline Flaxseed extract & $27.3 \%$ at $100 \mathrm{ppm}$ \\
DMSO & $5 \%$ at $100 \mathrm{ppm}$ \\
Negative control & $0 \%$ \\
\hline
\end{tabular}

Table 3 The antimicrobial activity of FM phenolic extracts determined by the agar well diffusion method on seven pathogenic indicator bacteria strains

\begin{tabular}{ll}
\hline Species of pathogenic bacteria & Flaxseed extract \\
\hline B.C, Bacillus cereus ATCC 33018 & Nil \\
List Listeria monocytogenes ATCC 7644 & 26 \\
Staph Staphylococcus aureus ATCC 20231 & $\mathrm{Nil}$ \\
sal Salmonella typhimurium ATCC 14028, & 25 \\
E.C Escherichia coli 0157: H7 ATCC 6933 & 22 \\
Psed Pseudomonas aeruginosa ATCC 9027 & 10 \\
Yersinin Yersinia enterocolitica ATCC 9610 & $\mathrm{Nil}$ \\
\hline
\end{tabular}

carcinoma cell line (HTC), lung carcinoma sell line (A549), liver carcinoma cell line (HEPG2) FM phenolic extract had no effect on normal fibroblasts. The highest inhibitory effect was achieved on cell lines of colon carcinoma and lung carcinoma with $\mathrm{IC}_{50}=22.3$ and $22.6 \mu$ / $\mathrm{ml}$. The next inhibited is the liver cell line carcinoma with $\mathrm{IC}_{50}=39.4 \mu / \mathrm{ml}$, this followed by intestinal carcinoma then breast carcinoma cell lines with $\mathrm{IC}_{50}=46.9$ and $49 \mu / \mathrm{ml}$.

\section{Discussion}

Previously, the same authors reported on the extraction of phenolic compounds (PC) from flaxseed meal using a variety of extraction techniques (Akl et al. 2017). The wide range of biological activities of the components of the flaxseed meal (e.g., the introduction part), initiated our interest to evaluate the biological activities of these phenolic extracts (antioxidant, antimicrobial, anticoagulation, and anticancer effects).

\section{Antioxidant activity of PC extracts from FM}

All living organisms utilize oxygen to metabolize and use the dietary nutrients to produce energy for survival. Oxygen thus is a vital component for living. Oxygen meditates chemical reactions that metabolize fats, proteins, and carbohydrates to produce energy. While oxygen is one of the most essential components for living, it is also a double-edged sword. Oxygen is a highly reactive atom that can become part of potentially damaging molecules commonly called "free radicals," which can attack the healthy cells of the body. This may lead to damage, disease, and severe disorders. Cell damage caused by free radicals appears to be a major contributor to aging and

Table 4 Effect of FM phenolic extracts on thrombin clotting time

\begin{tabular}{llll}
\hline & \multicolumn{3}{l}{ Thrombin time (s) } \\
\cline { 2 - 3 } & Final conc. $\mathrm{mg} / \mathrm{ml}$ & \\
\hline PC extractof FM & 5.0 & 2.0 & 1.0 \\
& 19.0 & - & - \\
\hline
\end{tabular}


Table 5 Anticarcinogenic effect of PC from FM, measured as $\mu \mathrm{g} / \mathrm{ml}$

\begin{tabular}{ll}
\hline$C_{50} \mu \mathrm{g} / \mathrm{ml}$ & \\
\hline Cell line & PC extract \\
BHK & - \\
CACO & 46.5 \\
MCF7 & 49 \\
HCT & 22.3 \\
A549 & 22.6 \\
HEPG2 & 39.4
\end{tabular}

$\mathrm{LC}_{50}$ is the lethal concentration of sample which causes the death of $50 \%$ of the cells in $48 \mathrm{~h}$

diseases like cancer, heart diseases, decline in brain function, and decline in immune system. Overall, free radicals have been implicated in the pathogenesis of at least 50 diseases.

Phenolic compounds are phytochemicals which play a major role in the protection of oxidation processes. The antioxidant properties of phenolic compounds can act as free radical scavengers, hydrogen donators, metal chelators, and singlet oxygen quenchers. It must be emphasized that most of the information on phenolic antioxidant potential comes from studies in vitro. There are several nutrients in food that contain antioxidants. Vitamin $C$, vitamin $E$, and $\beta$ carotene are among the most commonly studied dietary antioxidants [Chen et al. 1994; Malcolmson et al. 2000; Hosseinian et al. 2006].

Starting from the antioxidant activity and the following biological evaluations were all done on the semi-pilot scale prepared phenolic extract from FM.

The reducing power of a compound is related to its electron transfer ability and may serve as a significant indicator of its potent antioxidant activity. $\mathrm{Fe}^{+3} / \mathrm{Fe}^{+2}$ reducing power method is usually used for the determination of reducing power. In the reaction mixture, the presence of an antioxidant will reduce $\mathrm{Fe}^{+3}$ ferricyanide to $\mathrm{Fe}^{+2}$ ferrocyanide. The amount of $\mathrm{Fe}^{+2}$ can be determined by measuring the generation of Perl's Prussian blue at 700 $\mathrm{nm}$. Fu et al. (2014) concluded that all of three extracts of Jatropha curcas seed shell contained high contents of phenolic compounds and exhibited relatively strong antioxidant activities.

Slavova-Kazakova et al. (2016) studied antioxidant activity of flaxseed extracts in lipid systems. They reported that flaxseed extract, its alkaline hydrolysate, and SDG are not able to inhibit effectively lipid autoxidation in TGSO model. Both extracts act as natural antioxidants in a $\beta$-carotene-linoleate emulsion system. SECO exhibited a stronger activity than SDG.

Due to antioxidant properties in emulsion system, flaxseed extract and its hydrolysate can be used as natural antioxidants for meat, mayonnaise, and dressing, thus prolonging shelf life.

\section{Toxicity test}

Toxicology test is known as a safety assessment and is conducted to determine the degree to which a substance can damage living or non-living organisms. The concentration of the chemical in air that kills $50 \%$ of the test animals during the observation period is the $\mathrm{LC}_{50}$ value. Other durations of exposure (versus the traditional $4 \mathrm{~h}$ ) may apply depending on specific laws.

Phenolic antioxidants function as free radical terminators. Phenolic compounds and some of their derivatives are very efficient in preventing autoxidation; however, only a few phenolic compounds are currently permissible by law as food antioxidants. The major concerns for acceptability of such antioxidants are their activity and potential toxicity.

\section{The antimicrobial activity of PC extract from FM}

Phenolic compounds are produced by plants mainly for protection against stress and predators. The functions of phenolic compounds in plant physiology and interactions with biotic and abiotic environments are difficult to overestimate. Phenolics play important roles in plant development, particularly in lignin and pigment biosynthesis. They also provide structural integrity and support to plants. Importantly, phenolic phytoalexins, secreted by wounded or otherwise perturbed plants, repel or kill many microorganisms, and some pathogens can counteract or nullify these defenses or even disrupt them to their own advantage.

Thus, FM phenolic extract can be considered to have as antimicrobial activity. Gamal et al. (2011) working with guava seeds found the methanolic phenolic extract to exhibit antimicrobial activity. Taha et al. (2011) found that working with sunflower meal isolates chlorogenic acid (a phenolic compound) and that it had an antimicrobial activity and inhibited the growth of some food pathogens. Fernández-Lópeza et al. (2005) investigated the antioxidant and antibacterial effect of rosemary, orange, and lemon extracts in cooked Swedish-style meatballs. Activity in a lard system was established for all the extracts.

\section{Anticoagulation activity}

Flavanols have antioxidant, vasodilatory, anticoagulant, and anti-inflammatory properties. Flavanols have antidepressant effects on laboratory animals. Intake of flavanols enhances human cognitive performance and cerebral blood flow. Intake of flavanols such as dark chocolate counteracts negative emotions. Flavanol-rich cocoa-derived products may complement traditional antidepressant regimes. 
Antihemorrhagic action of plant phenolic compounds is primarily due to compaction, increasing the strength of vascular tissue barriers. But there is a certain importance and influence of phenols on coagulation of blood. Hesperidin, rutin, and ellagic acid reduced the duration of bleeding. It is well known that the citrine, rutin, and other drugs increase the amount of calcium in the blood involved in the coagulation process. Finally, the acceleration of coagulation can be achieved indirectly-adrenaline promotes the formation of blood clots and phenolic compounds to protect it from inactivation in the bloodstream.

Wee et al. (2010), in conclusion, stated that the phenolic compounds in KRG have potent anticoagulant activity, whereas the saponin fractions, which were previously shown to possess antiplatelet aggregation activity, do not. Taken together, these results suggest that both saponins and phenolic compounds contribute to the cardiovascular effects of KRG through their antiplatelet aggregation and anticoagulant activities, respectively. Additionally, in vivo studies of the anticoagulant activities of phenolic compounds will be useful to better understand the pharmacology of these compounds.

The results of coagulant activity of the phenolic extract mean that PC caused hardly any clotting perhaps because the phenolics known to delay clotting time are not present according to HPLC analysis reported by Akl et al. (2017). Only p-coumaric and not coumaric was present as $9.3 \mu \mathrm{g} / \mathrm{g}$ meals in FM. Hesperidin, rutin, and ellagic acid reduced the duration of bleeding, and coumarin anticoagulants are bound to serum proteins.

\section{Anticarcinogenic activity of PC from FM}

Saenglee et al. (2016) stated that phenolic compounds present in our diet play an important role in colon cancer chemoprevention. Previous results demonstrated that peanut testa extract inhibited both histone deacetylase (HDAC) activity and the growth of colon cancer cells.

Flaxseed is extensively consumed in three ways: whole seed, powder, and flaxseed oil. In the last decade, flaxseed has gained attention due to its reported health benefits. Studies have shown the benefits of flaxseed alphalinolenic acid (ALA), lignans, and fiber. The presence of these bioactive compounds helps in the prevention of cardiovascular diseases, diabetes, memory loss, and constipation. The phenolic compounds of flaxseed help in reduction of the fasting plasma glucose levels. Flaxseed contains biologically active estrogenic compounds called phytoestrogens which help in decreasing cell proliferation and prevents cancer. Higher levels of flaxseed are associated with prevention of memory loss and constipation. Flaxseed also contains several non-nutritional compounds such as cyanogenic glycosides, cadmium, trypsin inhibitors, and phytic acid that negatively influence health and well-being (Mishra and Verma 2013). Flaxseeds contain phenolic compounds called lignans, and secoisolariciresinol-diglucoside (SDG) is a major lignan with putative health benefits such as antioxidant and anticancer effects. The role of SDG and its metabolites such as enterolignans is gaining attention due to their mitigating effects against cancers especially prostate and breast cancer. Several epidemiological, in vitro and animal studies add evidence to this anticancer benefit of SDG. However, more research activities, especially clinical and pharmacokinetic studies in humans, are required to corroborate this evidence. The focus on the roles of SDG and its metabolites in preventing breast tumors, including an evaluation of potential mechanisms of action, was reviewed by Alphonse and Aluko (2015).

\section{Conclusion}

The biological activities of PC extracted from FM using the more effective extraction procedure (ultrasonic assisted extraction) showed high antioxidant activity when measured by the three methods. Also, toxicity test proved that the PC extract from FM was nontoxic on normal retina cell line. The FM extract showed almost no anticoagulating activities. The FM extract has antimicrobial effect on some pathogenic bacteria four out of seven. FM phenolic extract had no effect on normal fibroblasts. The highest inhibitory effect was achieved on cell lines of colon carcinoma and lung carcinoma followed by liver cell line carcinoma, then intestinal carcinoma, and then breast carcinoma cell. Therefore, the phenolic compounds extracted from flaxseed meal showed significant biological activities.

\section{Abbreviations}

${ }^{\circ} \mathrm{C}$ : Celsius; AA: Antioxidant activities; ALA: Alpha linolenic acid; ANOVA: Analysis of variance; BHT: Butylated hydroxyl toluene; CaAG: Caffeic acid glucoside; DIZ: Diameter of inhibition zone; DMSO: Dimethylsulphoxide; DPPH: 2,2-Diphenyl-1-picrylhydrazyl; FM: Flaxseed meal; FRAP: Ferric reducing antioxidant power; HPLC: High-performance liquid chromatography; MTT: 3(4,5-Dimethylthiazol-2-yl)-2,5-diphenyltetraazolium bromide; PC: Phenolic compounds; ROS: Reactive oxygen species; RT: Retention time;

SDG: Secoisolariciresinol diglucoside; SDS: Sodium dodecyl sulfate; SE: Soxhlet extraction; SECO: Secoisolariciresinol; TGSO: Triacylglycerols of sunflower oil; TPC: Total phenolic compounds; UAE: Ultrasonic-assisted extraction

\section{Acknowledgements}

The facilities offered to the authors by the Central Library at the National Research Centre, Cairo, Egypt, to collect the data of article are highly appreciated.

\section{Authors' contributions}

EA worked the experimented part and collected the data. FT, SM, and AH wrote, read, and approved the final manuscript.

\section{Funding}

The authors thankfully acknowledge the financial assistance of NRC which supported our study by project no. 10090003. 


\section{Availability of data and materials}

Not applicable.

\section{Ethics approval and consent to participate}

Not applicable.

\section{Consent for publication}

Not applicable.

\section{Competing interests}

The authors declare that they have no competing interests.

\section{Author details}

${ }^{1}$ Fats and Oils Department, National Research Centre, Dokki, Cairo, Egypt. ${ }^{2}$ Chemistry Department, Faculty of Science, Ain Shams University, Cairo, Egypt.

\section{Received: 11 October 2019 Accepted: 4 February 2020}

Published online: 17 February 2020

\section{References}

Adolphe JL, Whiting SJ, Juurlink BH, Thorpe LU, Alcorn J (2010) Health effects with consumption of the flax lignan secoisolariciresinol diglucoside. $\mathrm{Br} J$ Nutr. 103:929-938

Akl EM, Mohamed SS, Hashem Al, Taha FS (2017) Optimum extraction of phenolic compounds from flaxseed meal. Am J Food Technol 12:152-169

Alphonse AS, Aluko R (2015) Anti-carcinogenic and anti-metastatic effects of flax seed lignan secolariciresinol diglucoside (SDG). Phytomedicine 2:12-17

Ayella A, Lim S, Jiang Y, Iwamoto T, Lin D, Tomich J, Wang W (2010) Cytostatic inhibition of cancer cell growth by lignan secoisolariciresinol diglucoside. Nutr Res 30:762-769

Bassyouni FA, Abu-Baker SM, Mahmoud K, Moharam M, El-Nakkady SS, AbdelRehim M (2014) Synthesis and biological evaluation of some new triazolo[1,5-a]quinoline derivatives as anticancer and antimicrobial agents. RSC Advances 4(46):24131-24141

Benavente-García O, Castillo J, Marin FR, Ortuño A, Del Río JA (1997) Uses and properties of citrus flavonoids. J Agric Food Chem. 45:4505-4515

Bommareddy A, Zhang X, Schrader D, Kaushik RS, Zeman D, Matthees DP et al (2009) Effects of dietary flaxseed on intestinal tumorigenesis in Apc Min mouse. Nutr Cancer 61:276-283

Cai Y, Luo Q, Sun M, Corke H (2004) Antioxidant activity and phenolic compounds of 112 traditional Chinese medicinal plants associated with anticancer. Life Sci. 74:2157-2184

Chen ZY, Ratnayake WMN, Cunnane SC (1994) Oxidative stability of flax seed lipids during baking. J. Am. Oil Chem. Soc 71:629-632

Choo WS, Birch J, Dufour JP (2007) Physicochemical and quality characteristics of cold-pressed flaxseed oils. J Food Compos Anal. 20:202-211

Clark WF, Parbtani A, Huff MW, Spanner E, de Salis H, Chin-Yee I et al (1995) Flaxseed: a potential treatment for lupus nephritis. Kidney International 48: 475-480

Con A, Gokalp H, Kaya M (2001) Antagonistic effect on Listeria monocytogenes and Listeria innocua of bacteriocin-like metabolite produced by lactic acid bacteria isolated from sucuk. Meat Science. 59:437-441

Cunnane SC, Ganguli S, Menard C, Liede AC, Hamadeh MJ, Chen Z-Y et al (1993) High a-linolenic acid flaxseed (Linum usitatissimum): some nutritional properties in humans. Br J Nutr 69:443-453

Cutter C (2000) Antimicrobial effect of herb extracts against Escherichia coli 0157: h7, Listeria monocytogenes and Salmonella typhimurium associated with beef. J Food Prot. 63:601-607

Daud N., Hashim H. and Samsulrizal N. Anticoagulant activity of Averrhoa bilimbi Linn in normal and alloxan-induced diabetic rats. Open Conference Proceedings Journal, (Suppl-2, M6) 21-26 21 , 2210-2892/13; (2013).

Fernández-Lópeza J, Zhib N, Aleson-Carbonella L, Pérez-Alvareza JA, Kurib V (2005) Antioxidant and antibacterial activities of natural extracts: application in beef meatballs. Meat Sci 69(3):371-380

Fu R, Zhang Y, Guo Y, Liu F, Chen F (2014) Determination of phenolic contents and antioxidant activities of extracts of Jatropha curcas L. seed shell, a byproduct, a new source of natural antioxidant. Industerial Crops Products 58 : $265-270$
Gamal FM, Samira SS, Fakhriya ST (2011) Antioxidant, antimicrobial, and anticarcinogenic properties of phenolic extracts from Egyptian guava seeds. Nat Sci 9(11):32-41

Hemmings SJ, Westcott ND, Muir AD, Czechowicz D (2004) The effects of dietary flaxseed on the Fischer 344 rat: II. liver gamma-glutamyltranspeptidase activity. Cell Biochem Func 22:225-231

Hosseinian FS, Muir AD, Westcott ND, Krol ES (2006) Antioxidant capacity of flaxseed lignans in two model systems. J Am Oil Chem Soc. 83:835-840

Jenkins DJ, Kendall CW, Vidgen E, Agarwal S, Rao AV, Rosenberg RS et al (1999) Health aspects of partially defatted flaxseed, including effects on serum lipids, oxidative measures, and ex vivo androgen and progestin activity: a controlled crossover trial. American Journal of Clinical Nutrition 69:395-402

Johnsson P. Phenolic compounds in flaxseed: chromatographic and spectroscopic analyses of glucosidic conjugates. Licentiate thesis. 91-5766630-x. (2004).

Khouya T, Ramchoun M, Hmidani A, Amrani S, Harnafi H, Benlyas M, Zegzouti YF, Chakib AC (2015) 644Anti-inflammatory, anticoagulant and antioxidant effects of aqueous extracts from Moroccan thyme varieties. Asian Pac J Trop Biomed 5(8):636-644

Kim Y, llich JZ (2011) Implications of dietary alinolenic acid in bone health. Nutrition 27:1101-1107

Komutarin T, Azadi S, Butterworth L, Keil D, Chitsomboon B, Suttajit M, Meade BJ (2004) Extract of the seed coat of Tamarindus indica inhibits nitric oxide production by murine macrophages in vitro and in vivo. Food Chem. Toxicol. 42:649-658

Korkina LG (2007) Phenylpropanoids as naturally occurring antioxidants: from plant defense to human health. Cell Mol Biol. 15:15-25

Malcolmson LJ, Przybylski R, Daun JK (2000) Storage stability of milled flax seed. J Am Oil Chem Soc 77:235-238

Mishra S, Verma P (2013) Flaxseed-bioactive compounds and health significance. J Humanities Soc Sci 17(3):46-50

Muir A.D., Westcott N.D., A.D. Muir, N.D. Westcott. Taylor \& Francis London, Flaxseed constituents and human health. In: Flax, the genus linum. Eds 243251. (2003).

Oomah BD, Kenaschuk EO, Mazza G (1995) Phenolic acids in flaxseed. J Agriculture Food Chem 43:2016-2019

Oyaizu M (1986) Studies on products of browning reactions: antioxidant activities of products of browning reaction prepared from glucosamine. J Nutrit. 44: 307-315

Park JB, Velasquez MT (2012) Potential effects of lignan-enriched flaxseed powder on bodyweight, visceral fat, lipid profile, and blood pressure in rats. Fitoterapia 83:941-946

Przybylski R, Daun JK (2005) Additional data on the storage stability of milled flaxseed. J Am Oil Chem Soc 78:105-106

Rammelsberg M and F Radler (1990) Antibacterial polypeptides of Lactobacillus species. J. Appl Bacteriol 69:177-184

Rodriguez-Leyva D, Bassett CMC, McCullough R, Pierce GN (2010) The cardiovascular effects of flaxseed and its omega-3 fatty acid, alpha-linolenic acid. Can J Cardiol. 26:489-496

Saenglee S, Jogloy S, Patanothai A, Leid M, Senawong T (2016) Cytotoxic effects of peanut phenolics possessing histone deacetylase inhibitory activity in breast and cervical cancer cell lines. Turkish J BiologyTurk J Biol 40(23):1601

Serraino M, Thompson LU (1991) The effect of flaxseed supplementation on early risk markers for mammary carcinogenesis. Cancer Letters 60:135-142

Skehan P, Storeng R, Scudiero D, Monks A, McMohan J et al (1990) New calorimetric cytotoxicity assay for anticancer drug screening. J Natl Cancer Inst 82:1107-1112

Skórkowska-Telichowska K, Zuk M, Kulma A, Bugajska-Prusak A, Ratajczak K, Gassiorowski K, Kostyn K, Szopa J (2010) New dressing materials derived from transgenic flax products to treat long-standing venous ulcers-a pilot study. Wound Repair Regen 18:168-179

Slavova-Kazakova A, Karama' CM, Kancheva V, Amarowicz R (2016) Antioxidant activity of flaxseed extracts in lipid systems phytochemistry. Molecules 21:17. https://doi.org/10.3390/molecules21010017

Smid EJ, LGM G (1999) Natural antimicrobials for food preservation. In: Rahman MS (ed) Handbook of Food Preservation. Marcel Dekker, New York, pp 285-308

Taga MS, Miller EE, Pratt DE (1984) Chia seeds as a source of natural antioxidants. J Am Oil ChemSoc 61:928-931

Taha FS, Mohamed GF, Mohamed SS, Kamil MM (2011) Optimization of the extraction of total phenolic compounds from sunflower meal, and evaluation of the bioactivities of chosen extracts. Am J Food Technol 6:1002-1020 
Thompson LU, Seid MM, Rickard SE, Orcheson LJ, Fong HH (1996)

Antitumorigenic effect of a mammalian lignan precursor from flaxseed. Nutr Cancer 26:159-165

Tuberoso CIG, Kowalczyk A, Sarrizu E, Cabras P (2007) Determination of antioxidant compounds and antioxidant activity in commercial oilseeds for food use. Food Chem 103:1494-1501

Wang L, Chen J, Thompson LU (2005) The inhibitory effect of flaxseed on the growth and metastasis of estrogen receptor negative human breast cancer xenograftsis attributed to both its lignan and oil components. Int J Cancer 116:793-798

Wee JJ, Kim YS, Kyung JS, Song YB, Do JH KDC, Lee SD (2010) Identification of anticoagulant components in Korean red ginseng. J Ginseng Res 34(4):355362

Zhao H, Fan W, Dong J, Lu J, Chen J, Shan L (2008) Evaluation of antioxidant activities and total phenolic contents of typical malting barley varieties. Food Chem. 107:296-304

Żuk M, Dymińska L, Kulma A, Boba A, Prescha A, Szopa J, Mączka M, Zając A, Szoltysek K, Hanuza J (2011) IR and Raman studies of oil and seedcake extracts from natural and genetically modified flax seeds. Spectrochim. Acta A Mol. Biomol. Spectrosc. 78:1080-1089

\section{Publisher's Note}

Springer Nature remains neutral with regard to jurisdictional claims in published maps and institutional affiliations.

\section{Submit your manuscript to a SpringerOpen ${ }^{\circ}$ journal and benefit from:}

- Convenient online submission

- Rigorous peer review

- Open access: articles freely available online

- High visibility within the field

- Retaining the copyright to your article

Submit your next manuscript at $\boldsymbol{\nabla}$ springeropen.com 